Корнус // Фінанси України. - 2004. - №11. - C. 20-25.

8 Мунтян, Т.В. Податкове планування - як засіб зниження податкового тиску на суб'єктів підприємницької діяльності [Текст] / Т.В. Мунтян // Економіка: проблеми теорії та практики. - 2000. - Вип. 64. - С. 92-97.

$$
9 \text { Панченко, С.В. }
$$

Підприємництво [Текст]: підручник / С.В. Панченко, В.Л. Дикань, О.В. Шраменко, О.М. Полякова, Ю.М. Уткіна. Х.: УкрДУЗТ, 2016. - Ч.1. Теоретичні основи організації підприємницької діяльності. -241 с.

10 Панченко,

Підприсмництво [Текст]: підручник

С.В. Панченко, В.Л. Дикань, О.В. Шраменко, О.М. Полякова, Ю.М. Уткіна. Х.: УкрДУЗТ, 2016. - Ч.2. Реалізація підприємницької діяльності у сучасних ринкових умовах. $-241 \mathrm{c}$.

11 Панченко, С.В. Управління бізнесом [Текст]: підручник / С.В. Панченко, В.Л. Дикань, І.В. Воловельська, В.О. Маслова; За заг. ред. В.Л. Диканя. - Харків: УкрДУЗТ, 2016. $312 \mathrm{c}$.

12 Ткачик, Л. Оптимізаційна модель корпоративного податкового менеджменту [Текст] / Л. Ткачик // Вісник ЛНУ ім. I. Франка. Серія економічна. - 2012. - Вип. 47. - C. 434-443.

13 Шарікова, О.В. Податкове навантаження як фактор тінізації економіки: [Електронний ресурс] / О.В. Шарікова. - Режим доступу: www.rusnauka.com/19_NNM_2007/Econom ics/23354.doc.htm

DOI 10.18664/338.47:338.45.v0i64.149923

УДК 330.34:691

\title{
АНАЛІЗ СТАНУ ТА ТЕНДЕНЦІЙ РОЗВИТКУ РИНКУ БУДІВЕЛЬНИХ МАТЕРІАЛІВ УКРАЇНИ
}

\author{
Колесник А.В., студент, \\ Бутенко О.П., к.е.н., доцент (ХНУБА)
}

У статті розглянуто стан ринку будівельних матеріалів України. Проаналізовано кількість вироблених на території Украӥни будівельних матеріалів, оптовий та роздрібний товарообіг, експорт та імпорт будівельної продукиії. Виявлена залежність України від імпортованої будівельної продукиії. На основі проведеного аналізу виявлені причини гальмування розвитку досліджуваного ринку, та його залежності від будівельних матеріалів інших краӥн.

Ключові слова: ринок будівельних матеріалів, оптовий товарообіг, роздрібний товарообіг, експорт, імпорт, імпортозалежність.

(C) Колесник А.В., Бутенко О.П.
Вісник економіки транспорту і промисловості № 64, 2018 


\title{
АНАЛИЗ СОСТОЯНИЯ И ТЕНДЕНЦИЙ РАЗВИТИЯ РЫНКА СТРОИТЕЛЬНЫХ МАТЕРИАЛОВ УКРАИНЫ
}

\author{
Колесник А.В., студент, \\ Бутенко Е.П., к.э.н., доцент (ХНУСА)
}

В статье рассмотрено состояние рынка строительных материалов Украиньл. Проанализировано количество произведенных на территории Украины строительных материалов, оптовый и розничный товарооборот, экспорт и импорт строительной продукиии. Выявлена зависимость Украинь от импортируемой строительной продукиии. На основе проведенного анализа выявлены причины торможения развития исследуемого рынка, и его зависимости от строительных материалов других стран.

Ключевые слова: рынок строительных материалов, оптовый товарооборот, розничный товарооборот, экспорт, импорт, импортозависимость.

\section{ANALYSIS OF STATE AND TRENDS OF DEVELOPMENT OF UKRAINE CONSTRUCTION MATERIALS MARKET}

\author{
Kolesnik A.V., student, \\ Butenko O.P., Candidate of Economic Sciences, associate professor (KNUBA)
}

The article deals with the market of building materials of Ukraine, as the whole industry as a whole, as well as individual components. It is observed that together with the growth of production volumes in the industry, there was an increase in the cost of construction materials, as well as significantly changed their structure and assortment, which is a research issue. The work is carried out in order to identify problems and determine the prospects for the successful functioning of the market of building materials consumer orientation. On the basis of the analysis of researches of scientists generalizations of the main problems of the state of the market of building materials of Ukraine. Based on the findings and statistical data, the work focuses on the analysis of wholesale and retail trade, import and export of construction materials. The research is carried out taking into account the three components of which the production of building materials depends, namely on the raw material factor, consumer and transport. The authors analyze the reasons for the decrease and increase in sales of certain types of building materials, taking into account retail and wholesale sales of products. The article deals with such problems as insufficient technical equipment of the enterprises producing building materials, the level of their export and import. It is noted that the technological and technological lag in the industry leads to a narrower assortment and a lower quality of domestic products than to importers. The main products, which are imported in maximum volumes and minimum, are determined. The specified group of goods that are exported the most. The reasons for the low volumes of export of certain types of building materials are indicated. The authors conclude that the market for building materials has a tendency to increase both in volume and in value. It is indicated on the dependence of the market on imported products and the reasons that hinder the development of the market for building materials. Further research is planned to be carried out in the direction of minimization of factors hindering the development of the market for building materials and restraining the development of enterprises producing building materials.

Key words: market of building materials, wholesale trade, retail trade turnover, export, import, import dependence. 


\section{Постановка проблеми та ї̈ зв'язки 3 науковими чи практичними} завданнями. Будівельна галузь є однією 3 основних ланок господарювання в кожній країні. Вона тісно пов'язана, впливає та залежить від розвитку багатьох суміжних галузей таких як металургійна, деревообробна, машинобудівна, хімічна, легка промисловість тощо, тому стан будівельної галузі відображає економічний стан країни у цілому. Наразі, за підсумками 2017 року, підприємства України виконали будівельні роботи на суму 101,1 млрд грн, індекс будівельної продукції по відношенню до 2016 року склав 20,9\% [1]. Разом зі зростанням обсягів продукції у галузі, що свідчить про позитивну динаміку показників діяльності, відбулось і підвищення вартості будівельних матеріалів, а також значно змінилася їх структура та асортимент, що і є питанням дослідження.

Аналіз останніх досліджень $i$ публікацій. Дослідженням питання стану ринку будівельних матеріалів в Україні займалися Ю. І. Соха та К. В. Процак [2], які розглянули формування будівельного ринку в Україні, та проблеми, що гальмують його розвиток на макро - та мікрорівнях і визначили за головний перспективний напрям - впровадження системи управління якістю. У свою чергу, М. А. Пічугіна та Ю. К. Нужна [3], які проаналізували стан ринку будівельних матеріалів України вказали на управлінську неспроможність бізнесодиниць. В. О. Шевченко [4] зазначив, що сучасний стан ринку будівельних матеріалів в Україні характеризується збільшенням обсягів виробництва, зростанням цін на будівельну продукцію через підвищення нормативних вимог до продукції та поступовим переоснащенням виробництва. М. Ю. Назукін [5] провів аналіз наявності будівельної сировини в Україні, та вказав на потенціал галузі у самостійному забезпеченні сировиною виробництво будівельних матеріалів усіх видів. Підсумовуючі дослідження зазначених авторів, головними проблемами на ринку будівельних матеріалів України є такі [4,5]:

-недостатня інформованість про стан будівельного ринку;
-недостатня
нормативно

законодавча база;

-недостатня кількість власних

фінансових ресурсів у підприємств виробників будівельних матеріалів, низька рентабельність підприємств;

-недостатня кількість як

вітчизняних, так і іноземних інвестицій;

-нестабільність економічної

ситуації;

-висока витратомісткість продукції, фізичне та моральне зношення обладнання підприємств - виробників будівельної продукції.

Виділення невирішених частин загальної проблеми. Враховуючи сучасні реалії стану розвитку ринку будівельних матеріалів, автори вважають за потрібне дослідження зміни асортименту та вартості будівельних матеріалів споживчої та сировинної орієнтації, які $є$ індикатором рівня технологій, якості, характеристикою управлінської можливості підприємців, а також стану економіки країни загалом.

Метою cmammi с аналіз ринку будівельних матеріалів, його асортименту та визначення проблем i перспектив успішного функціонування.

Виклад основного матеріалу дослідження. За твердженням В. I. Борейко розрізняють дві групи галузей виробництва будівельних матеріалів: сировинної орієнтації (виробництво цементу, азбестоцементних i шиферних виробів, вогнетривів, скла, керамічних труб, вапна тощо); споживчої орієнтації (виробництво бетону, залізобетонних виробів i конструкцій, м'якої покрівлі тощо) [6]. У свою чергу, будівельний комплекс складається із п'яти складових: виробництво будівельних матеріалів, будівництво, будівельне машинобудування та проектні й дослідно- 
конструкторські будівельні роботи. Перша складова, виробництво будівельних матеріалів залежить від трьох факторів: сировинного, споживчого та транспортного. Розглядаючи транспортну складову, можна зазначити, що процес будівництва вимагає величезних обсягів матеріалів, у зв'язку з чим, організовувати їх доставку з інших країн виявляється дуже дорого. Оцінки показують, що перевезення будматеріалів на відстані більше 450 км нерентабельні [7]. Тому іпортозалежність, за думкою деяких авторів, у цій галузі вважається невисокою. Щодо сировинної складової, варто сказати, що Україна багата на природну будівельну сировину: вогнетривкі глини, каоліни, кварцити, будівельний камінь тощо. Галузь виробляє матеріали, деталі й конструкції для всіх видів будівництва. Основна ії продукція стінові (цегла, бетонні й гіпсобетонні панелі, шлакоблоки), в'яжучі (цемент, вапно, будівельний гіпс), покрівельні (черепиця, шифер, толь, руберойд), оздоблювальні, облицювальні, ізоляційні матеріали, будівельне скло, збірний залізобетон і бетон, покрівельні кераміка i фаянс, санітарно-технічні вироби тощо [8, 9]. Важливим для аналізу Українського ринку будівельних матеріалів є споживчі характеристики, які формують обсяги виробництва продукції та іiі асортимент. Доцільно проаналізувати динаміку обсягів будівельної продукції за останні роки, результати зведені до в табл. 1.

Виробництво певних видів промислової продукиії на Україні

Таблиия 1 $(2013-2017 p)[10]$

\begin{tabular}{|l|c|c|c|c|c|}
\hline \multicolumn{1}{|c|}{$\begin{array}{c}\text { Найменування продукції за Номенклатурою продукції } \\
\text { промисловості (НПП), одиниця вимірювання }\end{array}$} & \multicolumn{3}{|c|}{ Вироблено (валовий випуск) за } \\
\cline { 2 - 6 } & 2013 & 2014 & 2015 & 2016 & 2017 \\
\hline $\begin{array}{l}\text { Фарби та лаки на основі поліакрилових чи вінілових полімерів, } \\
\text { дисперговані чи розчинені у водному середовищі (уключаючи } \\
\text { емалі та політури), тис.т }\end{array}$ & 73,5 & 66,7 & 60,7 & 74,6 & 76,0 \\
\hline $\begin{array}{l}\text { Фарби та лаки інші, дисперговані чи розчинені у водному } \\
\text { середовищі, тис.т }\end{array}$ & 16,0 & 15,9 & 18,5 & 17,2 & 18,3 \\
\hline $\begin{array}{l}\text { Фарби та лаки, включаючи емалі та політури, на основі } \\
\text { складних поліефірів, дисперговані чи розчинені в летких } \\
\text { органічних розчинниках (крім тих, які з вмістом розчинника } \\
\text { більше 50\% маси розчину), тис.т }\end{array}$ & 67,6 & 51,7 & 43,4 & 53,1 & 55,5 \\
\hline Плитки та плити, керамічні, млн.м & & & & & \\
\hline $\begin{array}{l}\text { Цегла невогнетривка керамічна будівельна (крім виробів з } \\
\text { борошна кам’яного кремнеземистого чи грунтів діатомітових), } \\
\text { тис.м }\end{array}$ & 2154 & 2229 & 2192 & 2190 & 2082 \\
\hline $\begin{array}{l}\text { Цемент глиноземистий, цемент безклінкерний шлаковий і } \\
\text { цементи гідравлічні подібні, млн.т }\end{array}$ & 0,3 & 0,2 & 0,2 & 0,3 & 0,3 \\
\hline Розчини бетонні, готові для використання, млн.т & 15,5 & 12,3 & 12,5 & 15,7 & 18,2 \\
\hline $\begin{array}{l}\text { Суміші будівельні сухі (крім розчинів бетонних, готових для } \\
\text { використання), тис.т }\end{array}$ & 1759 & 1601 & 1574 & 1702 & 2209 \\
\hline $\begin{array}{l}\text { Шлаковата, вата мінеральна силікатна та вати мінеральні } \\
\text { подібні (включно суміші), у блоках, листах чи рулонах, тис.т }\end{array}$ & 155 & 175 & 177 & 182 & 182 \\
\hline $\begin{array}{l}\text { Болти із шестигранними головками з металів чорних (крім зі } \\
\text { сталі неіржавної), з межею міцності на розтяг менше 800 МПа, } \\
\text { тис.т }\end{array}$ & 14,0 & 14,0 & 9,6 & 8,0 & 8,9 \\
\hline $\begin{array}{l}\text { Болти із шестигранними головками з металів чорних (крім зі } \\
\text { сталі неіржавної), з межею міцності на розтяг 800 МПа і } \\
\text { більше, тис.т }\end{array}$ & 4,7 & 2,3 & 2,5 & 5,8 & 5,1 \\
\hline Гайки інші, уключаючи самостопорні, з металів чорних, тис.т & 8,8 & 10,0 & 8,0 & 7,6 & 8,0 \\
\hline
\end{tabular}


Графічне зображення виробництва графік виробництва розчинів бетону цементу, будівельних сумішей, шлаковати, складено за даними табл.1.

загального обсягу виробництва фарби,

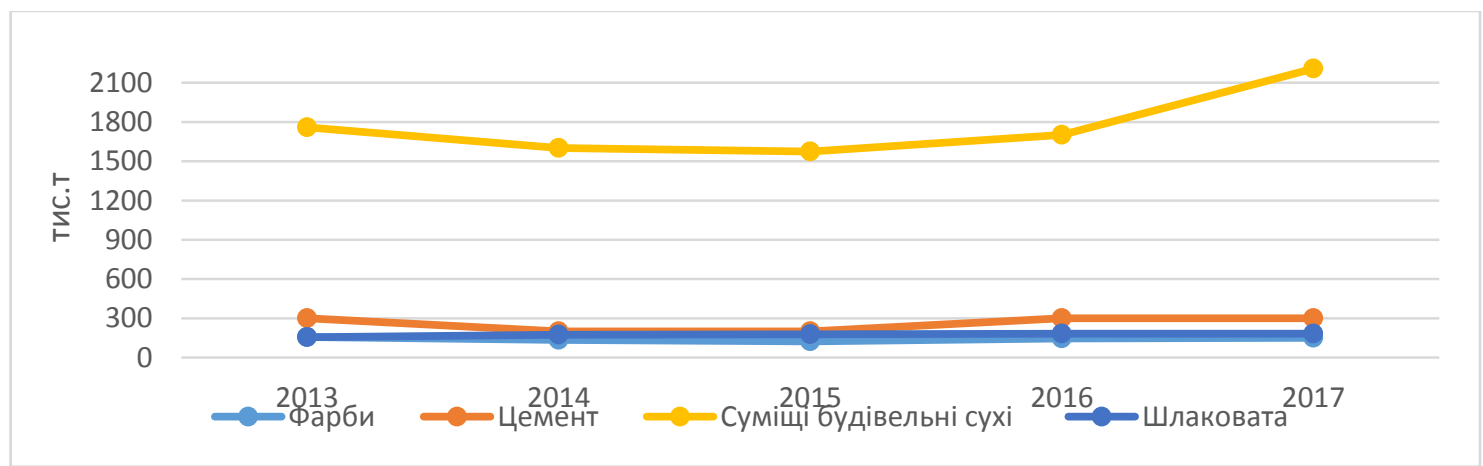

Рис. 1. Графік виробництва деяких видів будівельних матеріалів

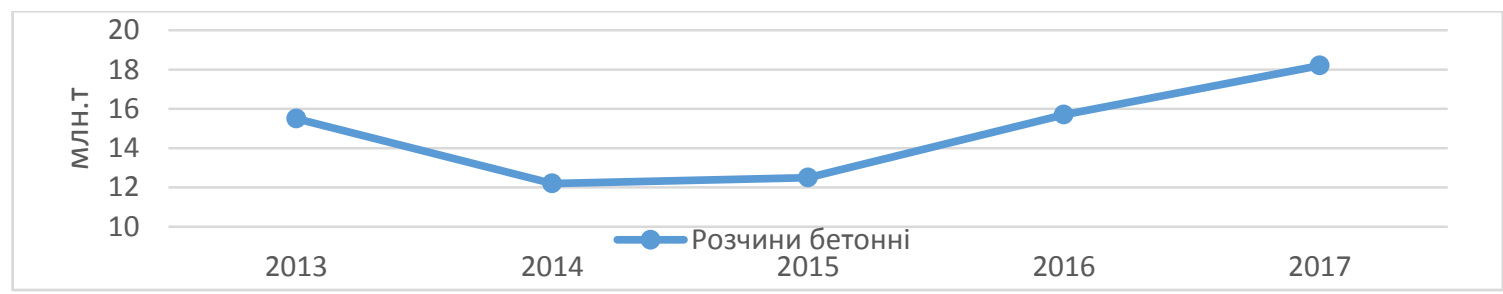

Рис. 2. Графік виробництва розчину бетонів

Результати аналізу свідчать, що для деяких видів продукції спадом стали 2014 2015 роки. У період 2016 - 2017 роки, стан виробництва будівельної продукції покращується, певна продукція повертається до стану 2013 року, а такі матеріали як лаки і фарби, шлаковата та сухі будівельні суміші перевищують рівень 2013 року. Це пов'язано, на думку авторів, 3 нестабільним політичним становищем в Україні в ті роки, зі скороченням обсягів виробництва та будівництва в країні. Для підприємств, що виробляють та реалізують будівельну продукцію, важливим показником $\epsilon$ обсяги оптового та роздрібного товарообігу будівельних матеріалів. Динаміка обсягів товарообігу будівельних матеріалів зведена до табл. 2 3.

Аналіз статистичних даних свідчить, що відсоток реалізованої оптом будівельної продукції, яка вироблена в Україні, є дещо стабільна, однак $\epsilon$ великі зміни по певним групам товарів. Так, відсоток продажу цементу зменшився на $12 \%$ порівняно 32016 роком, гуртові продажі виробів з асфальту впали з 65,8\% до 19,1\%. Це відбулося в наслідок низки причин, а саме через втрату деяких заводів в АР Крим та на сході України, а також розриву зв'язків 3 Росією, яка була головним експортером клінкеру цементу [11].

За даними таблиці можна сказати, що роздрібний товарообіг в Україні є досить стабільним, та загальна частка роздрібно проданих будівельних товарів, що виготовили в Україні, складає приблизно $50 \%$. Таким чином, кількість реалізованої будівельної продукції має тенденцію до збільшення, однак, кількість товарів Українського виробництва, що реалізуються оптом, мають певні проблеми. Що ж стосується роздрібного продажу, то кількість українських товарів, що реалізуються $\epsilon$ досить стабільним. 
Таблиия 2

Оптовий товарообіг будівельних матеріалів України [Складено за джерелом 10]

\begin{tabular}{|c|c|c|c|c|c|c|c|c|c|}
\hline & \multicolumn{3}{|c|}{2016} & \multicolumn{3}{|c|}{2017} & \multicolumn{3}{|c|}{1 пол 2018} \\
\hline & \multirow[t]{2}{*}{$\begin{array}{l}\text { Оптови } \\
\text { й } \\
\text { товаро- } \\
\text { оборот } \\
\text { тис.грн }\end{array}$} & \multicolumn{2}{|c|}{$\begin{array}{l}\text { У тому числі } \\
\text { продано товарів, } \\
\text { які вироблені на } \\
\text { території України }\end{array}$} & \multirow[t]{2}{*}{$\begin{array}{l}\text { Оптовий } \\
\text { товаро- } \\
\text { оборот } \\
\\
\text { тис.грн }\end{array}$} & \multicolumn{2}{|c|}{$\begin{array}{l}\text { У тому числі } \\
\text { продано товарів, } \\
\text { які вироблені на } \\
\text { території України }\end{array}$} & \multirow[t]{2}{*}{$\begin{array}{l}\text { Оптови } \\
\text { й } \\
\text { товаро- } \\
\text { оборот } \\
\text { тис.грн }\end{array}$} & \multicolumn{2}{|c|}{$\begin{array}{l}\text { У тому числі } \\
\text { продано товарів, } \\
\text { які вироблені на } \\
\text { території } \\
\text { України }\end{array}$} \\
\hline & & $\begin{array}{l}\text { тис. } \\
\text { грн }\end{array}$ & $\begin{array}{l}\text { у } \% \\
\text { до } \\
\text { відпо } \\
\text { відно } \\
\ddot{1} \\
\text { товар } \\
\text { ної } \\
\text { групи }\end{array}$ & & тис.грн & $\begin{array}{l}\text { у \% } \\
\text { до } \\
\text { відпо } \\
\text { відної } \\
\text { товар } \\
\text { ної } \\
\text { групи }\end{array}$ & & тис.грн & $\begin{array}{l}\text { у \% до } \\
\text { відпов } \\
\text { ідної } \\
\text { товар } \\
\text { ної } \\
\text { групи }\end{array}$ \\
\hline $\begin{array}{l}\text { Санітарно- } \\
\text { технічне } \\
\text { обладнання, } \\
\text { тис.грн } \\
\end{array}$ & 3008831 & 1237742 & 41,1 & 4240786,7 & 1638253 & 38,6 & 2245636,5 & 909148,6 & 40,5 \\
\hline $\begin{array}{l}\text { Фарби, лаки та } \\
\text { емалі, т }\end{array}$ & 4081267 & 1507340 & 36,9 & 4613355,9 & 1756444 & 38,1 & 2379603 & 963906,6 & 40,5 \\
\hline $\begin{array}{l}\text { Скло листове, } \\
\text { тис.грн }\end{array}$ & 2537397 & 222321,6 & 8,8 & 3189073,9 & 268648,2 & 8,4 & 1093069,7 & 74832,4 & 6,8 \\
\hline $\begin{array}{l}\text { Портландцеме } \\
\text { нт, цемент } \\
\text { глиноземний, } \\
\text { цемент без } \\
\text { клінкерний } \\
\text { шлаковий і } \\
\text { цементи } \\
\text { гідравлічні } \\
\text { подібні, т }\end{array}$ & 4804383 & 4572143 & 95,2 & 6304155,8 & 5679403 & 90,1 & 2887820,6 & 2410464 & 83,5 \\
\hline $\begin{array}{l}\text { Вироби } \\
\text { азбестоцемент } \\
\text { у, цементу } 3 \\
\text { волокнами } \\
\text { целюлози або } \\
\text { подібних } \\
\text { матеріалів, } \\
\text { тис.грн }\end{array}$ & 290193,3 & 233306,8 & 80,4 & 540284 & 432136 & 80 & 386670 & 293820,3 & 76 \\
\hline $\begin{array}{l}\text { Вироби } \\
\text { асфальту } \\
\text { подібних } \\
\text { матеріалів, } \\
\text { тис.грн }\end{array}$ & 423178 & 289567,4 & 68,4 & 622025,2 & 351961,1 & 56,6 & 1198482,5 & 229034,5 & 19,1 \\
\hline $\begin{array}{l}\text { Інші } \\
\text { будівельні } \\
\text { матеріали, } \\
\text { тис.грн }\end{array}$ & $\begin{array}{c}1677278 \\
8\end{array}$ & 11030963 & 65,8 & 27263963 & 18242125 & 66,9 & 15156920 & 10019201 & 66,1 \\
\hline $\begin{array}{l}\text { Шпалери, } \\
\text { покриття для } \\
\text { підлоги (крім } \\
\text { килимів), } \\
\text { тис.грн }\end{array}$ & 1420522 & 401806,3 & 28,3 & 1689481,2 & 326800,1 & 19,3 & 1073137,6 & 304357,8 & 28,4 \\
\hline
\end{tabular}


Таблиия 3

Роздрібний товарообіг будівельної продукиії в Украӥні [Складено за джерелом 10]

\begin{tabular}{|c|c|c|c|c|c|c|c|c|c|}
\hline & \multicolumn{3}{|c|}{2016} & \multicolumn{3}{|c|}{2017} & \multicolumn{3}{|c|}{1 пол. 2018} \\
\hline & \multirow[t]{2}{*}{$\begin{array}{l}\text { Роздріб } \\
\text {-ний } \\
\text { товаро- } \\
\text { оборот } \\
\\
\text { тис.грн }\end{array}$} & \multicolumn{2}{|c|}{$\begin{array}{l}\text { У тому числі } \\
\text { продано товарів, } \\
\text { які вироблені на } \\
\text { території України, } \\
\text { через торгову } \\
\text { мережу }\end{array}$} & \multirow[t]{2}{*}{$\begin{array}{l}\text { Роздріб- } \\
\text { ний } \\
\text { товаро- } \\
\text { оборот } \\
\\
\text { тис.грн }\end{array}$} & \multicolumn{2}{|c|}{$\begin{array}{l}\text { У тому числі } \\
\text { продано товарів, } \\
\text { які вироблені на } \\
\text { території } \\
\text { України, через } \\
\text { торгову мережу }\end{array}$} & \multirow{2}{*}{$\begin{array}{l}\text { Роздр } \\
\text { іб- } \\
\text { ний } \\
\text { товар } \\
\text { о- } \\
\text { оборо } \\
\text { т } \\
\text { тис.г } \\
\text { рн }\end{array}$} & \multicolumn{2}{|c|}{$\begin{array}{lr}\text { У } \\
\text { пому } & \text { числі } \\
\text { продано товарів, які } \\
\text { вироблені } \\
\text { території } \\
\text { через } \\
\text { мераїни, } \\
\text { межу } & \text { торгову } \\
\end{array}$} \\
\hline & & тис.грн & $\begin{array}{l}\text { у \% до } \\
\text { відпов } \\
\text { ідної } \\
\text { товар } \\
\text { ної } \\
\text { групи }\end{array}$ & & $\begin{array}{l}\text { тис.гр } \\
\text { н }\end{array}$ & $\begin{array}{l}\text { у \% до } \\
\text { відпові } \\
\text { дної } \\
\text { товарн } \\
\text { ої } \\
\text { групи }\end{array}$ & & тис.грн & $\begin{array}{l}\text { у \% до } \\
\text { відпові } \\
\text { дної } \\
\text { товарно } \\
\text { ї групи }\end{array}$ \\
\hline $\begin{array}{l}\text { Матеріали } \\
\text { будівельні } \\
\text { залізні вироби }\end{array}$ & 13513755 & 7794815 & 57,7 & 14081240 & $\begin{array}{c}785144 \\
7\end{array}$ & 55,8 & $\begin{array}{l}988744 \\
7\end{array}$ & 5483690 & 55,5 \\
\hline у тому числі & & & & & & & & & \\
\hline $\begin{array}{l}\text { лісоматеріали та } \\
\text { вироби будівельні } \\
\text { дерев'яні }\end{array}$ & 1747506 & 1138156 & 65,1 & 1982866 & $\begin{array}{c}126374 \\
9\end{array}$ & 63,7 & $\begin{array}{c}142365 \\
2\end{array}$ & 844371 & 59,3 \\
\hline $\begin{array}{l}\text { матеріали } \\
\text { будівельні } \\
\text { мінеральні } \\
\text { неметалеві } \\
\text { (цегла, будівель } \\
\text { ний } \\
\text { цемент, шамінь, } \\
\text { черепиця, вапно, } \\
\text { крейда, алебастр } \\
\text { (гіпс), } \\
\text { віконне та інші) }\end{array}$ & 3736448 & 2269553 & 60,7 & 3908300 & $\begin{array}{c}225734 \\
0\end{array}$ & 57,8 & $\begin{array}{c}267075 \\
6\end{array}$ & 1584133 & 59,3 \\
\hline $\begin{array}{l}\text { фарби, лаки та } \\
\text { емалі }\end{array}$ & 1471314 & 846229 & 57,5 & 1651213 & 989267 & 59,9 & $\begin{array}{c}119303 \\
0\end{array}$ & 721941 & 60,5 \\
\hline $\begin{array}{l}\text { санітарно- } \\
\text { технічне, } \\
\text { водопровідне } \\
\text { опалювальне } \\
\text { устаткування } \\
\text { приладдя } \\
\end{array}$ & 2159454 & 926295 & 42,9 & 2468017 & $\begin{array}{l}105648 \\
9\end{array}$ & 42,8 & $\begin{array}{l}181554 \\
7\end{array}$ & 774526 & 42,7 \\
\hline $\begin{array}{l}\text { залізні вироби та } \\
\text { iнші будівельні } \\
\text { матеріали }\end{array}$ & 4399033 & 2614583 & 59,4 & 4070845 & $\begin{array}{c}228460 \\
2\end{array}$ & 56,1 & $\begin{array}{l}278446 \\
\quad 2\end{array}$ & 1558719 & 56 \\
\hline
\end{tabular}

За даними Державної служби статистики України виробництвом будівельних матеріалів в Україні займається майже 9 тисяч підприємств, більша частина яких зосереджена у Київський, Львівській, Харківській, Донецькій, Сумській та Житомирській областях [5]. Проте більшість українських виробництв в цій галузі характеризуються технічним та технологічним відставанням, що зумовлює вужчий асортимент та нижчу якість продукції, ніж в імпортерів. Важливими показниками для визначення стану галузі є експорт та імпорт продукції, сальдо зовнішньої торгівлі та коефіцієнт покриття імпорту експортом. У табл. 4 наведена кількість експортованих та імпортованих виробів 3 каменю, гіпсу та цементу. 
Таблиия 4

Експорт-імпорт виробів з каменю, гіпсу та цементу [Складено за джерелом 10]

\begin{tabular}{|c|c|c|c|c|c|c|}
\hline \multirow[b]{2}{*}{ Рік } & \multicolumn{2}{|c|}{ Експорт } & \multicolumn{2}{|c|}{ Імпорт } & \multirow[b]{2}{*}{$\begin{array}{c}\text { С3Т* } \\
\text { млн.дол. } \\
\text { США }\end{array}$} & \multirow[b]{2}{*}{$\begin{array}{c}\text { Кпо }{ }^{* *}, \\
\%\end{array}$} \\
\hline & $\begin{array}{l}\text { млн.дол. } \\
\text { США }\end{array}$ & $\begin{array}{l}\text { \% до } \\
\text { попереднього } \\
\text { періоду }\end{array}$ & млн.дол.США & $\begin{array}{l}\text { \% до } \\
\text { попереднього } \\
\text { періоду }\end{array}$ & & \\
\hline 2014 & 479,3 & 82,3 & 801,5 & 71,1 & $-322,2$ & 59,80 \\
\hline 2015 & 331,6 & 69,2 & 509,9 & 63,6 & $-178,3$ & 65,03 \\
\hline 2016 & 298,5 & 90 & 605,8 & 118,8 & $-307,3$ & 49,27 \\
\hline 2017 & 363,9 & 121,9 & 651,4 & 107,5 & $-287,5$ & 55,86 \\
\hline $\begin{array}{l}\text { Січень- } \\
\text { липень } \\
2018\end{array}$ & 236,8 & 117,2 & 423,7 & 119,2 & $-186,9$ & 55,88 \\
\hline
\end{tabular}

*СЗТ - сальдо зовнішньої торгівлі

**Кпо - коефіцієнт покриття імпорта експортом

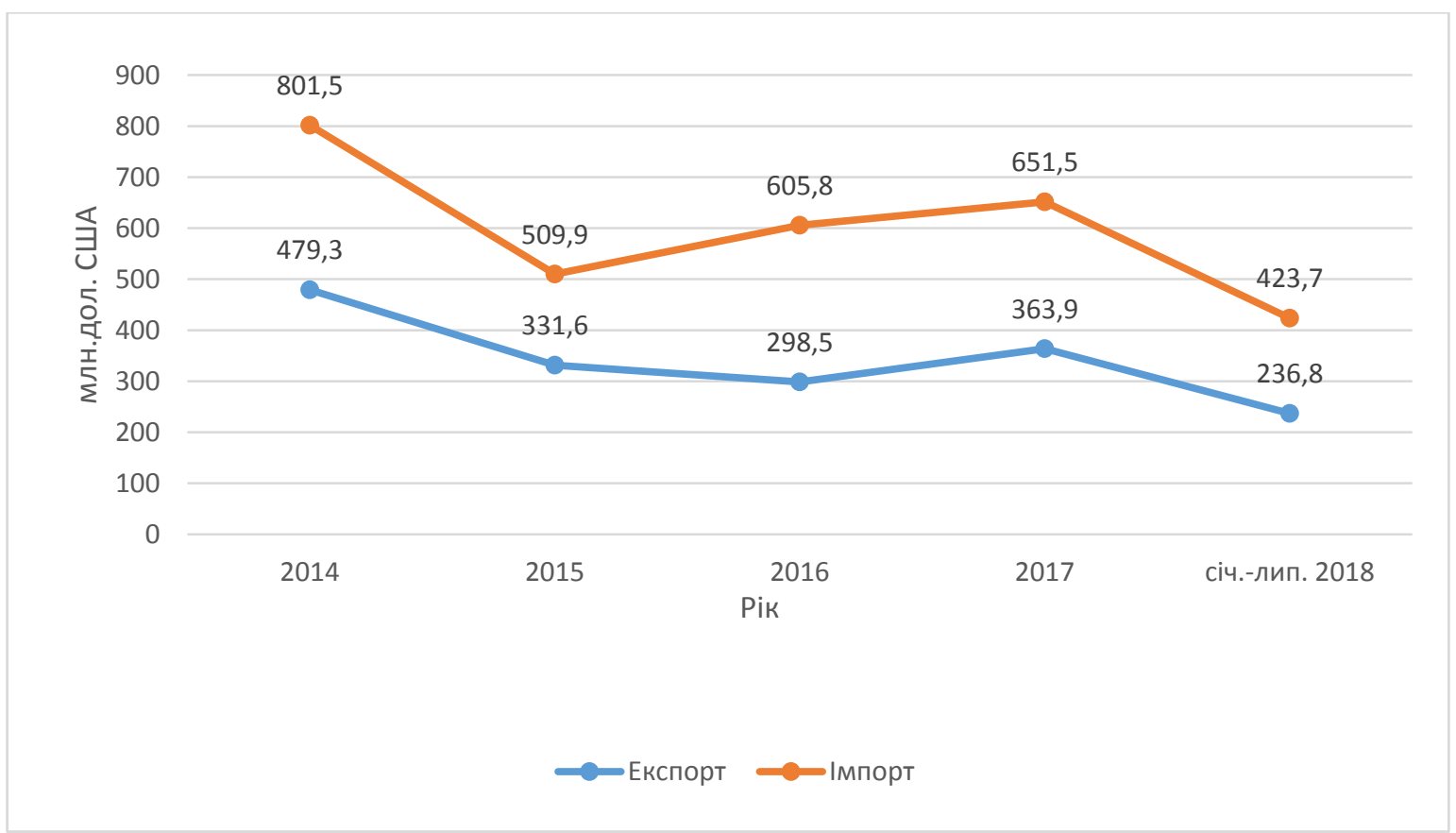

Рис. 3. Динаміка експорту та імпорту виробів з каменю, гіпсу, цементу за 2014-18 р.

Результати свідчать, що 3 кожним роком кількість виробів 3 каменю, гіпсу та цементу, що імпортовані на територію України, збільшується 3 кожним роком. Однак, можливість перекривати імпорт експортом в середньому становить $57 \%$. Це ще раз підтверджує те, Україна $\epsilon$ імпортозалежною у галузі будівельних матеріалів. На думку авторів, причинами зростання імпортозалежності є, у першу чергу, невідповідність продукції смакам споживачів, до якої відносяться такі характеристики як якість, покращені властивості, дизайн виробів, ціна. Імпорозалежніть підтверджує думку, що на вироблені в Україні будівельні матеріали існує достатньо сильна прив'язка до курсової різниці гривні та долара/євро, що свідчить про те, що вартість вітчизняних матеріалів залежить від вартості імпортованих складових [12]. У табл. 5 вказані дані максимальних та мінімальних експортних та імпортних поставок будівельних матеріалів. 
Експорт-імпорт будівельних матеріалів, тис.дол.

[Складено автором за джерелом 10]

\begin{tabular}{|c|c|c|c|c|c|c|c|c|c|}
\hline \multicolumn{5}{|c|}{ Експортовані товари } & \multicolumn{5}{|c|}{ Імпортовані товари } \\
\hline Товар & $\begin{array}{l}\text { Min } \\
\text { max }\end{array}$ & 2016 & 2017 & $\begin{array}{c}\text { Січ.-лип. } \\
2018\end{array}$ & Товар & $\begin{array}{c}\operatorname{Min} \\
\max \end{array}$ & 2016 & 2017 & $\begin{array}{l}\text { Січ.- } \\
\text { лип. } \\
2018\end{array}$ \\
\hline $\begin{array}{l}\text { Глини } \\
\text { вогнетрив } \\
\text { кі }\end{array}$ & $\max$ & 170127,9 & 235990,2 & 1165170,0 & $\begin{array}{l}\text { Глини } \\
\text { вогнетривкі }\end{array}$ & $\min$ & 422,7 & 189,9 & 147,8 \\
\hline $\begin{array}{l}\text { Абразивні } \\
\text { матеріали }\end{array}$ & $\min$ & 25,3 & 204,7 & 73,7 & $\begin{array}{l}\text { Абразивні } \\
\text { матеріали }\end{array}$ & $\min$ & 231,2 & 186,1 & 164,8 \\
\hline Вапняки & $\min$ & 8,8 & 37,8 & 96,9 & Вапняки & $\max$ & 22992,7 & 49256,9 & 40918,6 \\
\hline Азбест & $\min$ & 2,8 & 2,0 & - & Цементи & $\max$ & 23077,1 & 61716,5 & 25805,9 \\
\hline $\begin{array}{l}\text { Панелі, } \\
\text { пити, } \\
\text { блоки }\end{array}$ & $\min$ & 12,2 & 45,4 & 40,4 & $\begin{array}{l}\text { Панелі, } \\
\text { плити, блоки }\end{array}$ & $\min$ & 239,1 & 481,2 & 268,1 \\
\hline $\begin{array}{l}\text { Галька, } \\
\text { гравій, } \\
\text { щебінь }\end{array}$ & $\max$ & 39520,4 & 52110,2 & 31029,8 & Брущатка & $\min$ & 13,4 & 2,1 & 1,7 \\
\hline $\begin{array}{l}\text { Вироби } 3 \\
\text { асфальту }\end{array}$ & $\min$ & 153,0 & 156,5 & 96,4 & Шлаковата & $\max$ & 19624,7 & 18121,6 & 24017,1 \\
\hline
\end{tabular}

Результати спостережень такі:

-основними товарами, що експортуються Україною у дуже великих розмірах є глини вогнетривкі та галька, гравій, щебінь. Це пояснюється наявністю значної кількості цих природних копалин на теренах країни. Мінімально експортованими будівельними матеріалами $\epsilon$ абразивні матеріали, вапняки, панелі та плити, вироби 3 асфальту. Такий результат можливий через недостатню технічну оснащеність на розвиненість підприємств, які займаються виготовленням цих матеріалів. Тобто, ця продукція, значною мірою, може не відповідати стандартам якості інших країн. -найбільш імпортованими товарами $\epsilon$ вапняки, цементи та шлаковата. На думку авторів, це пов'язано з такими проблемами як недостатній розвиток виробництва, якість, яка не задовольняє потреби будівництва, зависока ціна через великі витрати виробництв, залежність від іноземних складових та інші.

-товарами, які імпортуються менше всього $є$ глини вогнетривкі, абразивні матеріали та брущатка. Такий стан пов'язаний 3 низьким попитом на споживчому ринку саме на цю номенклатуру продукції.

Висновки даного дослідження $i$ перспективи подальших робіт у цьому напрямку. Наразі, ринок будівельних матеріалів має тенденцію зростання. Спостерігається ріст загальної частки роздрібно проданих будівельних товарів, що виготовлені в Україні, що свідчить про зростання показників обсягів будівництва 
взагалі і, особливо, у приватному секторі. Більшість українських виробництв галузі характеризуються технічним та технологічним відставанням, що зумовлює вужчий асортимент та нижчу якість продукції, ніж в імпортерів. Використання, в значній мірі, імпортованої продукції призводить до імпортозалежності країни від будівельних матеріалів інших країн. Причинами зростання імпортозалежності $\epsilon$, у першу чергу, невідповідність продукції смакам споживачів, до якої відносяться такі характеристики як якість, покращені властивості, дизайн виробів, ціна. Автори вважають, що на вироблені в Україні будівельні матеріали існує достатньо сильна прив'язка до курсової різниці гривні та долара/євро. Група продукції, що експортується, відноситься до сировинної (глини вогнетривкі та галька, гравій, щебінь). Абразивні матеріали, вапняки, панелі та плити, вироби 3 асфальту експортуються мінімально через невідповідність якісних та технічних характеристик [13]. Основними причинами , що гальмують розвиток ринку будівельних матеріалів $\epsilon$ : недостатня інформованість про стан природних ресурсів, стану галузі та ринку, що не дає змогу виробляти необхідну кількість для задоволення власного ринку; законодавча база, що встановлює значний відсоток на імпортований товар, стримує розвиток підприємств; недостатнє фінансування підприємств; відсутність інвестицій через великі відсоткові ставки, що впливає на стан виробничої бази, не даючи можливості модернізувати підприємства.

Подальше дослідження потрібно проводити у напряму мінімізації причин, що гальмують розвиток ринку будівельних матеріалів та стримують розвиток підприємств-виробників будівельних матеріалів.

ПЕРЕЛІК ВИКОРИСТАНИХ ДЖЕРЕЛ

1. Парцхаладзе Л. Будівельна галузь України за рік зросла на 21\%
[Електронний ресурс] / Лев Парцхаладзе // Главком. - 2018. - Режим доступу до pecypcy:

https://glavcom.ua/economics/finances/budiv elna-galuz-ukrajini-za-rik-zrosla-na-21-

468242.html.

2. Соха Ю. I. Формування будівельного ринку України [Електронний ресурс] / Ю. I. Соха, К. В. Процак. - 2009. Режим доступу до ресурсу: http://ena.lp.edu.ua/bitstream/ntb/2451/1/28.p df.

3. Пічугіна М. А. Аналіз стану ринку будівельних матеріалів України [Електронний ресурс] / М. А. Пічугіна, Ю. К. Нужна // Збірник наукових праць "Сучасні підходи до управління підприємством". - 2016. - Режим доступу до pecypcy: http://spu.fmm.kpi.ua/article/view/73057/683 88.

4. Шевченко В. О. Стан i перспективи розвитку ринку будівельних матеріалів України [Електронний ресурс] / В. О. Шевченко // Ефективна економіка. 2014. - Режим доступу до ресурсу: http://www.economy.nayka.com.ua/?op $=1 \& \mathrm{z}$ $=3124$.

5. Назукін М. Ю. Особливості виробництва будівельних матеріалів та їх вплив на побудову управлінського обліку i контролю / М. Ю. Назукін. // Економічні науки. Сер. : Облік і фінанси.. - 2013. №10. - С. 14-24.

6. Борейко B. I. Перспективи виробництва будівельних матеріалів в Україні [текст] / В.I. Борейко, М.Ю. Притула // Збірник наукових праць. Проблеми раціонального використання соціально-економічного та природноресурсного потенціалу регіону: фінансова політика та інвестиції. - 2011. - Випуск XVII, № 4. - C. 64-71.

7. Слюсаренко О. Ю. Проблеми розвитку промисловості / О. Ю. Слюсаренко. // Вісник НТУ «ХПІ». - 2015. - №28. - C. 118-122.

8. Романчук А. Л. Оцінка сучасного стану промисловості будівельних 
матеріалів: "вузькі місця" та переспективи подальшого розвитку [Електронний peсурс] / А. Л. Романчук - Режим доступу до ресурсу: http://chteiknteu.cv.ua/herald/content/download/archive/ 2012/v1/1-2012-25.pdf.

9. Андрєєва Т. Є. Оптимальне використання сировинної бази підприємствами будівельного комплексу // Т. Є. Андрєєва, О. П. Бутенко / - Будівельне виробництво, №57, 2014 - С. 17-19

10. Державна служба статистики України [Електронний ресурс] - Режим доступу до ресурсу: http://www.ukrstat.gov.ua.

11. Pro consalting. Аналіз ринку цементу (в т. ч. цементних клінкерів), бетону (товарний бетон та ін.) України. 2018 рік [Електронний ресурс] / Pro consalting // Дослідження ринків. - 2018. -
Режим доступу до ресурсу: https://proconsulting.ua/ua/issledovanie-rynka/analizrynka-cementa-v-t-ch-cementnyh-klinkerovbetona-tovarnyj-beton-i-dr-ukrainy-2018god.].

12. Пацюк E. C. Комплекс маркетинга на предприятиях промышленности строительных материалов / Е. С. Пацюк. - Волгоград: Волгоградский государственный технический университет, 2006. - 154 с.

13. В жилом строительстве доля импортных материалов превышает 15-20\% от общего объема необходимых аналитики [Електронний ресурс]. - 2018. Режим доступу до ресурсу: https://stroyobzor.ua/news/v-zhilomstroitelstve-dolya-importnyh-materialovprevyshaet-15-20-ot-obshchego-obemaneobhodimyh-analitiki.html.

DOI 10.18664/338.47:338.45.v0i64.149930

UDC 338.27+338.242.2

\title{
EVALUATION OF EV MARKET EXPANSION ON THE PERSPECTIVES OF ELECTRIC POWER ENGINEERING DEVELOPMENT IN UKRAINE
}

\author{
Krutsyak M., PhD student ( National Technical University of Ukraine "Igor \\ Sikorsky Kyiv Polytechnic Institute»)
}

The analysis of factors that lead to the changes in the market situation for electricity and changes of the development vector of electric power industry in Ukraine, respectively, is carried out. The state and condition of Ukrainian power industry in the coordinates of technology development are determined.

Established in the conditions provided by the current New energy strategy of Ukraine, it should be expected the deficit of electricity in the market and the increasing of the consumption by electric vehicles to the domestic consumers level. The potential influence of the rapid growth of the Ukrainian market of electric vehicles on the general situation in the power industry is determined. The works of the world-renowned experts in the field of energy economy, the statistical data and a number of basic legislative acts concerning the electricity market in Ukraine were analyzed.

The methodological basis to conduct the research is chosen and grounded. The structure of electricity consumption, main fuel, energy resources of the fuel and energy complex of Ukraine is presented. The dynamics of the electric power industry and the market of cars and 